\title{
The Effects of 'Dialogic Reading' on Story Retelling of Children with Language Disabilities at Ages 6 and 7
}

\author{
Young-Hee Kang ${ }^{\mathrm{a}}$, Gyung-Hun Hong ${ }^{\mathrm{b}}$ \\ ${ }^{a}$ Child Development Center of Mom and Sori, Cheonan, Korea \\ ${ }^{b}$ Department of Communication Disorders, Korea Nazarene University, Cheonan, Korea
}

Correspondence: Gyung-Hun Hong, PhD Department of Communication Disorders, Korea Nazarene University, 48 Wolbong-ro, Seobuk-gu, Cheonan 31172, Korea

Tel: $+82-41-570-7868$

Fax: $+82-41-570-7846$

E-mail: ghun@kornu.ac.kr

Received: December 30, 2015

Revised: February 13, 2016

Accepted: February 17, 2016

This work is based on the master's thesis of the first author.
Objectives: The purpose of the present study was to investigate the effects of 'dialogic reading' strategies on the story retelling of children with language disabilities. Methods: Participants were 3 children with language disabilities at ages 6 to 7 . Data was collected for 3 baseline, 16 experimental, and 3 follow-up sessions. PEER (Prompt, Evaluate, Expand, and Repeat) strategies of 'dialogic reading' were used to prompt the expressive responses of the children while reading a book. Analyzed variables were 'story grammar' and 'properties of story grammar' for macrostructure and total number of T-units, total number of words (TNW), mean length of T-unit-word (MLT-w), clausal density and subordinate clauses for microstructure of narratives. Results: For all participants all variables of story retelling increased through the experimental phase and were maintained in the follow-up phase. In terms of macrostructure, 'character', initiating event,', plan', and 'consequence' showed especially large increases. In addition, 'internal response' and 'attempt', which were rarely seen in baseline, were observed with increasing frequency. All microstructure variables showed rapid increases during the intervention period. Conclusion: The strategies of dialogic reading' revealed strong effects on both the macrostructure and microstructure of story retelling of children with language disabilities at ages 6 and 7 .

Keywords: Dialogic-reading, Children with developmental language delays, Story retelling, Story grammar, T-unit, Subordinate clause
잘 구성된 이야기는 단순한 문장들의 나열이 아닌 연계성 있는 체계적인 조직체여야 한다. 이야기를 구성하는 문장들의 세련됨 또 한 이야기의 수준에 영향을 미치는 주요 요소이다. 따라서 이야기 분석은 주로 대형구조(macrostructure)와 소형구조(microstructure)를 포함한다. 대형구조는 이야기 문법과 같이 이야기의 전체적 인 조직에 관한 단위이며, 소형구조는 대형구조 안에 사용된 발화 나 텍스트의 길이, 구문의 복잡성, 결속장치 등이 포함된다. 이처럼 이야기는 다양한 언어적 요소들을 통합할 수 있는 메타언어적인 능력뿐만 아니라 문제해결 전략과 정보의 회상 및 통합이 가능한 인지 능력이 요구되는 과제이다. 이런 이유로 이야기는 특히 학령기 에 달성해야하는주요한 과업이 된다.

이야기 문법은 이야기 구조를 생성하는 통사적 규칙뿐만 아니라 그에 상응하는 의미표상을 결정하는 의미해석 규칙에 대한 아동의
수준을 평가하는 데 적절하다. 따라서 많은 연구들에서 문장 수준 을 넘어선 담화 수준의 평가가 필요한 아동들에 대한 주요 언어평 가 영역으로 제안되었다(Mandler, 1978; Merritt \& Liles, 1987; Morrow, 1986; Page \& Stewart, 1985). 또한 Liles, Duffy, Merritt과 Purcell (1995)은 유치원과 초등 저학년 언어장애 아동들과 일반 아동 들의 이야기 산출을 대형구조와 소형구조 측면에서 분석한 결과, 소형구조 관련 변인들이 언어장애를 잘 변별해주는 효과적인 예측 요인이었다고 제시한 바 있다.

언어학습에 결함이 있는 아동들은 시간과 인과관계에 대한 이 해와 이야기 구성에 필요한 구조적인 지식의 발달에 어려움을 보인 다(Westby, Van Dongen, \& Maggart, 1989). 어휘나 문장 수준에서 는 정상발달 범위를 나타내는 언어발달지체 아동들이 이야기 수 준에서 또래보다 지체되었다는 연구결과들(Montague, Maddux, 
\& Dereshiwsky, 1990; Ripich \& Griffith, 1988)은 언어발달지체의 이력이 있는 아동들이 상위언어 수준에서 지속적인 결함을 나타낼 위험성을 시사한다. 관련 연구들은 일반적으로 언어발달에 결함이 있는 아동들이 일반 또래에 비하여 제한적인 이야기 문법 유형을 산출하며, 평균 T-unit의 길이가 짧고, 단순한 구문을 사용한다고 보고하였다(Cheon \& Kim, 2007; Merritt \& Liles, 1987; Morrow, 1985; Pae \& Kwon, 2006; Page \& Stewart, 1985). 따라서 이야기는 언어발달 결함을 가진 아동들에 대한주요한 평가 및 중재 영역이다.

책 읽기는 언어 이전 시기의 아동들이 접하는 일상적인 활동이 면서 언어발달을 촉진할 수 있는 주요 활동이다(Beals, 2001; Ninio, 1980). 일반적으로 아동들이 가장 먼저 접하게 되는 책의 유형은 그 림책으로 그림은 언어 학습을 용이하게 해주는 중요한 단서로 작 용한다. 따라서 그림책은 언어발달을 촉진하는 매우 효과적인 도구 가 된다. Whitehurst와 동료들(Whitehurst et al., 1988, 1994; Whitehurst \& Lonigan, 1998)은 그림책을 사용한 '대화식 책 읽기(dialogic reading)' 전략을 소개하고, 연구를 통하여 이 전략이 어린 아 동들의 어휘 및 문장 발달 촉진에 매우 긍정적인 효과가 있음을 보 고하였다. 이들이 제안한 '대화식 책 읽기’란 성인과 유아가 책을 보 는 상황에서 체계적인 언어적 상호작용을 통해 유아가 단순한 청자 가 아닌 적극적인 화자가 되도록 유도하여 언어 산출을 촉진하는 방법이다. 그림책 읽기의 맥락 안에서 아동의 언어에 대한 성인의 피드백과 이야기에 대한 생각을 표현하는 아동의 산출 경험이 아 동의 언어발달을 촉진한다는 Whitehurst 등(1994)의 이론을 기반 으로 하였다. 대화식 책 읽기의 교수 방법은 언어치료 현장에서 많 이 사용되는 ‘촉진(Prompt)', '평가(Evaluate)', '확장(Expend)', '반 복(Repeat)'의 기법들의 체계적인 사용으로 'PEER' 전략이라 제시 하였다.

그림책을 사용한 ‘대화식 책 읽기’의 언어발달 촉진 효과에 대한 최근의 한 연구(Lever \& Sénéchal, 2011)는 이 전략이 학령전기 후 반 아동들의 어휘, 구문뿐만 아니라 이야기 산출 능력의 향상에도 긍정적인 효과가 있음을 보고하였다. 연구자들은 유치원 연령의 일 반 아동들을 두 집단으로 나누어 8주 동안 대화식 책 읽기와 음운 인식 중재를 각각 실시한 후 이야기문법, 이야기결속표지, 문장복 잡성, 수용 및 표현어휘 능력을 비교한 결과, 대화식 책 읽기를 실시 한 실험집단이 모든 영역에서 더 높은 향상을 나타냈다고 보고하 였다. 이 연구는 주로 어린 유아들에게 사용했던 대화식 책 읽기의 PEER 전략이 학령전기 후반 아동들의 어휘, 구문 및 이야기 발달 촉진에도 효과가 있음을 시사했다는 점에서 의미가 있다. 이 외에 도 성인이 아동과 대화를 나누듯이 책을 읽는 방식이 아동들의 어 휘나 구문뿐만 아니라 이야기 산출 및 이해 그리고 읽기 및 쓰기와
같은 문해 능력의 향상에 효과적이라는 연구들도 보고된 바 있다 (Crain-Thoreson \& Dale, 1999; Lecci, Karoly, Briggs, \& Kuhn, 1994; Whitehurst et al., 1988, 1994; Whitehurst \& Lonigan, 1998).

국내에서는 일반 영유아나 언어발달지체 아동의 수용 및 표현어 휘 발달 촉진에 대한 '대화식 책 읽기'의 효과를 보고한 연구들은 많이 있으나(Lee \& Kim, 2004; Oh, Kim, \& Lee, 2008; Park \& Kim, 2010), 담화 수준 이상에 대한 효과를 검증한 연구는 찾아보기 어 렵다. 언어발달에서 어휘나 구문의 습득이 학령전기의 주요 습득 과제라면 이야기 발달은 학령기의 주요 과제이다. 많은 전문가들은 학령전기의 이야기 발달을 학령기 이후의 언어뿐만 아니라 학업과 또래 관계형성 수준을 예측하는 중요한 요인으로 제시하고 있다 (Bishop \& Adams, 1992; Bishop \& Edmundson, 1987; Morrow, 1985). 따라서 학령기를 준비해야 하는 학령전기 후반의 언어발달 지체 아동들에게 이야기 능력의 발달은 매우 중요한 과업이다. 그 러므로 이야기 발달을 촉진하는 효과적인 중재 전략의 발견은 임 상현장에서 매우 시급하며 중요한 의미를 갖는다.

앞서 기술한 바와같이 이야기의 대형구조와 소형구조 관련 변인 들은 이야기 구성을 위한 필수요소들로써 효과적인 중재 전략을 위해 반드시 고려해야 하는 요인들이다. 이에 본 연구는 대화식 책 읽기 기법을 사용한 중재가 6-7세 언어발달지체 아동들의 이야기 회상 산출 능력에 미치는 효과를 검증하였다. 이를 위해 대화식 책 읽기의 PEER 전략의 중재 효과를 대형구조 관련 변인들인 이야기 문법 전체 산출점수 및 유형별 산출점수 그리고 소형구조 관련 변 인들인 T-unit 산출 수, MLT-w, 절밀도 및 종속절 유형별 산출률 측면에서 분석하였다.

\section{연구 방법}

\section{연구대상}

연구 대상은 충남 천안에 거주하는 만 6-7세의 언어발달지체 아 동 3명으로 공통적인 선정기준은 다음과 같다(Table 1). (1) 구문의 미이해력검사(Pae, Lim, Lee, \& Chang, 2004)와 언어문제해결력검 사(Pae, Lim, \& Lee, 2000)에서 10\%ile 미만인 아동으로, (2) K-WISCIV (Kwak, Oh, \& Kim, 2011)의 동작성 지능이 70 이상이고, (3) 신 체, 신경, 정서, 사회성, 감각 등의 발달에서 중복 장애가 없고, (4) 최 근 3 개월 이내 전문기관에서 이야기 중재를 받지 않은 아동을 대상 으로 하였다.

아동 A

아동 $\mathrm{A}$ 는 7 세의 1 학년 여자 아동이었다. 어머니 보고에 의하면 
Table 1. Characteristics of participants

\begin{tabular}{lccc}
\hline Characteristic & A & B & C \\
\hline Gender & F & M & F \\
Age (yr;mo) & $7 ; 0$ & $6 ; 6$ & $7 ; 3$ \\
K-WISC-IV (nonverbal IO) & 76 & 70 & 70 \\
KOSECT (\%ile) & 11 & $1 \downarrow$ & 3 \\
TOPS (\%ile) & 3 & 11 & $1 \downarrow$ \\
\hline
\end{tabular}

K-WISC-IV = Korean-Wechsler Intelligence Scale for Children-IV (Kwak, Oh, \& Kim, 2011); KOSECT = Korean Oral Syntax Comprehension Test (Pae, Lim, Lee, \& Chang, 2004); TOPS= Test of Problem Solving (Pae, Lim, \& Lee, 2000).

아동이 3세경 또래에 비해 언어가 느리다는 것을 알았으나 초등학 교를 입학하기 3 개월 전부터 언어치료를 시작하여, 약 1년 동안 언 어치료를 받고 있다고 하였다. 학기 초에 반 친구들과의 관계를 형 성하는 데 많이 힘들어 했으나, 아동의 언어문제를 이해해주는 담 임선생님의 배려로 현재는 친구들과 큰 어려움 없이 잘 지내고 있 다고 하였다. 현재 일상적인 대화는 큰 무리가 없으나 자신의 말 문 제를 인식해서 자신 없는 경우에는 일부러 발음을 흐리거나 목소 리를 작게 하는 등의 불명료한 산출을 보인다고 한다.

연구자가 처음 아동과 만났을 때 낯가림이 심하여 양육자와의 분리가 잘 되지 않았고 연구자와 3 회 정도의 만남 이후에야 양육자 와의 분리가 되어 연구자와 아동이 독립적 공간에서 평가할 수 있 었다.

구문의미이해력검사(Pae et al., 2004)에서는 사동과 피동문의 이해 그리고 비유적 표현이나 유추가 필요한 구문의 이해에 어려움 을 나타냈다. 언어문제해결력검사(Pae et al., 2000)에서는 원인과 이유에 대한 질문에 대부분 단답형으로 대답하였으며 추론 질문 에는 관련이 없는 대답이나 모른다는 대답이 대부분이었다. 자연 스런 대화를 통한 이야기 산출 유도 결과, 학교에서 있었던 일이나 저녁에 동생과 있었던 일과 같은 일상적인 주제에 대해서 등장인물 과 장소, 사건을 포함한 간단한 이야기가 가능하였다. 그러나 연구 자가 좀 더 구체적인 상황을 묻는 질문들에는 자신이 없는 듯 불명 료하게 발음을 흐리는 특성을 보였다. 또한 이야기 도중 몇몇 단어 들은 유사한 단어로 대체하거나 에두르기를 나타냈다. 전반적으로 아동 $\mathrm{A}$ 는 의사소통 기능이나 행동에서는 특별한 문제를 보이지 않 았으나, 복잡한 구문의 산출 및 이해, 상황에 대한 구체적인 설명이 나추론에 어려움을 보였으며, 제한된 어휘사용을 나타냈다.

아동 B

아동 B는 6세 6개월 된 유치원생 남자 아동이었다. 어머니 보고 에 의하면 4 세경 언어치료를 시작하였으나 1 년 정도 치료를 받다가 중단하였으며, 6 세쯤 다시 언어치료를 시작하였다고 한다. 아동은
현재 유치원에 재학 중이며 또래관계에서는 남자 아이들보다 주로 여자 아이들과 어울려 논다고 한다.

아동은 연구자와 함께 만났을 때부터 '언제 또 만나요?'라고 묻 는 등 연구자에게 친밀하게 다가왔으며, 다음 만남에 대해 기대하 는 모습을 보였다. 아동은 그림 보는 것을 좋아하였고, 중재자와 하 는 활동에 끝까지 집중하는 집중력을 보였다.

구문의미이해력검사(Pae et al., 2004)에서 사동 및 피동문과 비 유적 표현의 이해에 어려움을 보였다. 언어문제해결력검사(Pae et al., 2000)에서는 주로 한 두 낱말의 단답형으로 대답하였으며, 추 론 질문에는 주로 그림과 관련이 없는 대답을 나타냈다. 자연스런 대화를 통한 이야기 산출 유도 결과, 아동의 경험과 관련된 이야기 산출 시에 복문 산출이 나타났으나 주로 단문을 사용하였으며, 실 제로 경험하지 않은 상황을 이야기하는 특성을 보였다(예: 이사를 하지 않았음에도 '주택으로 이사를 갔어요'). 전반적으로 복잡한 구문 이해와 상황에 대한 원인과 결과 추론에 어려움을 보였고, 경 험에 대한 설명에는 제한을 나타냈다.

아동 C

아동 C는 7세 3 개월의 1 학년 여자 아동이었다. 부모님에 의하면 아동은 18 개월까지 산출 어휘가 없었으며, 4 세경에 두 낱말 조합 산출 수준을 나타냈다고 한다. 4 세에 언어치료를 시작하여 1년간 치료를 받았으며, 5 세경에는 짧은 이야기 산출이 가능하였다고 한 다. 아동이 5 세 때 아빠의 직장 관계로 중국에 가서 2 년 정도 생활 하다가 6세말쯤 한국으로 돌아왔다고 한다. 현재 아동은 학교생활 에서 또래와의 관계는 어려움이 없지만 학습에서 많은 문제를 보인 다고 한다. 현재 언어치료를 받고 있지 않지만 조만간 언어치료를 받을 계획이 있다고 한다.

아동은 연구자와 처음 만났을 때 낯가림이 심한 편이었고, 연구 자와 대화를 하거나 연구자가 하는 질문에 엄마를 보며 대답을 머 뭇거린다거나 대답을 하지 않는 등의 모습을 보였다. 아동은 연구자 와 3 번을 만난 후에야 엄마와 분리가 가능하였다.

구문의미이해력검사(Pae et al., 2004)에서 특히 관형절이 내포된 문장의 이해에 어려움을 보였으며, 은유적 표현과 사동 및 피동문 에서 오류를 보였다. 언어문제해결력검사(Pae et al., 2000)에서는 주로 단답형의 대답을 하였으며, 특히 추론 질문에는 그림과 관련 없는 대답이나 모른다는 대답이 대부분이었다. 연구자와의 대화에 서 복문 산출과 간단한 경험에 대한 이야기 산출은 가능하였으나 '그렇게 했어요.', '거기 있잖아요.', '그거 말이에요.'와 같은 대용어 사용을 많이 나타내며 종종 구체적인 상황 설명에 어려움을 보였 다. 전반적으로 복잡한 복문에 대한 이해와 추론에서 어려움을 보 
였으며, 간단한 이야기 산출이 가능하나 대용어 사용이 많은 특성 을 보였다.

\section{연구도구}

중재 및 평가에 사용된 그림책은 '호기심 많은 조지 시리즈'(The Curious George Collection; Ray \& Rey, 1994, 1998a, 1998b, 1998c, 1998d, 1998e, 1999, 2001a, 2001b, 2002a, 2002b, 2004, 2005, 2006) 로 조지라는 원숭이와 그와 같이 사는 '노란 모자를 쓴 아저씨'를 중심으로 일상생활에서 흔히 일어나는 다양한 사건들을 그림과 글 로 구성한 유아용 그림책이다. 그 중 예비 조사를 통해 대상자들의 생활 및 언어 연령과 이야기 구성의 적합성, 그림의 완성도, 문화나 사회 환경의 적절성 등을 고려하여 학교, 병원, 극장 관련 에피소드 등 6-7세 아동들에게 친숙한 주제로 선정하였다. 조지 시리즈는 Cheon과 Kim (2007), Naremore, Densmore와 Harman (1995)에 의해 유아의 언어발달 촉진이나 이야기 산출에 적절한 책으로 추 천된 바 있다. 본 연구에 사용한 그림책은 원래 책을 그대로 사용하 지 않고, 책에 인쇄되어 있는 영어문장을 지우고 각 장면을 칼라로 복사한 후에 새롭게 제본하여 사용하였다. 이때 그림의 크기는 14.8 $\mathrm{cm} \times 21 \mathrm{~cm}$ 사이즈로 재구성하였으며, 재질은 구겨지거나 찢어지 지 않고 넘기기 쉽도록 두꺼운 종이를 사용하였다. 그림의 각 장면 에서 아동에게 들려줄 이야기는 각 장면에 맞추어 연구자가 따로 스크립트를 구성하여 준비하였다. 특히 평가에 사용한 그림책들과 스크립트는 각 종속변인인 그림 장면 수 11장, 이야기 문법 수(에피 소드 2 개, 배경 2 개, 계기사건 4 개, 계획 4 개, 내적반응 4 개, 시도 4 개, 결과 4 개), T-unit 수 20 개의 노출 빈도를 일치시켰다. 평가에서 아동에게 들려준 이야기는 연구자의 목소리로 녹음을 하여 준비 하였다. 그림책은 훈련용 5 권, 평가용 8 권으로 나누어 총 13 권을 사 용하였다. 모든 책들은 동일한 주제가 겹치지 않도록 하였으며, 훈 련용과 평가용은 위의 기준으로 우선 선정한 주제들 중에서 랜덤 으로 분류하였다.

\section{실험 설계}

본 연구는 대상 아동 3 명에 대한 중다 기초선 설계(multiple baseline design)로 실시하였다.

\section{실험 절차}

기초선 평가부터 유지까지 각 아동별로 기초선 3-4회기, 중재 16 회기, 유지 3회기로 총 22-23회기를 진행하였다. 자료 수집은 주 3 회 실시하였으며, 유지 평가는 중재 종료 후약 10 일 후에 진행하였다.

\section{기초선 단계}

기초선 평가는 아동과 충분한 라포 형성 후에 아동이 엄마와 분 리되어 연구자와 단 둘이 수행이 가능할 때부터 실시하였다. 기초 선 단계의 평가에서는 아동들에게 평가방법에 대한 설명만을 제공 하고, 그 외에는 어떠한 설명이나 피드백도 제공하지 않았다. 기초 선 자료는 중재 이후의 진전 효과와 비교하기 위하여 평가용 8 권 중에서 동일한 3 권의 책을 모든 아동들에게 사용하였으며, 아동들 간에 책의 순서가 동일하지 않도록 조절하였다.

\section{중재 단계}

회기별로 평가 10 분과 중재 30 분 순서로 진행하였다.

PEER 전략을 사용한 대화식 책 읽기

본 연구에서 사용한 대화식 책 읽기 전략은 Whitehurst와 동료 들(Whitehurst et al., 1994; Whitehurst \& Lonigan, 1998; Zevenbergen \& Whitehurst, 2003)이 제시한 PEER 전략으로 구체적으로 '촉진(Prompt)', '평가(Evaluate)', '확장(Expand)', '반복(Repeat)'의 기법을 사용한 대화식 책 읽기이다. 대화식 책 읽기는 성인이 아동 과 책을 읽는 동안 일방적인 책 읽어주기가 아니라 대화를 사용한 상호작용적인 책 읽기를 통하여 아동의 참여기회를 높이고 이를 통하여 아동의 언어발달을 촉진하는 데 목적이 있다.

PEER 전략의 구체적인 진행 순서는 다음과 같다. 먼저 성인이 아 동과 그림책을 같이 보며 읽어 준 후에 그림책을 다시 보면서 적절 한 촉진 기법을 사용하여 아동의 발화를 촉진(Prompt)한다. 촉진 의 하위 기법에는 '문장완성하기(Completion)', '회상하기(Recall)', '개방적 질문하기'(Open-ended), '의문사 질문하기'(Wh-questions), '경험과 연관시키기(Distancing)'의 5 가지 기법들이 있으며 첫 알파 벳을 조합하여 'CROWD'라고 한다.

'문장 완성하기'는 책 이야기와 관련된 중요한 단어나 구를 포함 하는 문장의 일부를 성인이 제시하고 빈 부분을 아동이 채워 말하 도록 하여 완전한 문장형태를 경험하게 한다. '회상하기'는 들려준 이야기에 관한 질문을 통해 이야기의 구조와사건의 순서를 이해하 게 한다. '개방적 질문하기'와 ‘의문사 질문하기'는 아동이 책의 그 림을 단서로 하여 회상할 수 있도록 그림에 나타난 사물, 상황 또는 사건에 대한 질문을 통해 아동의 산출을 촉진한다. 이때 '개방적 질 문하기'는 그림에서 일어나고 있는 상황에 대해 아동이 스스로 묘 사해 보도록 개방형 질문(예: ‘이 그림에서 무슨 일이 일어났어?')을 사용하여 촉진한다면 ‘의문사 질문하기'는 성인이 관련 그림을 직 접적으로 가리키며(pointing), 구체적인 의문사(예: 조지가 낚시하 는 그림을 가리키며 (조지가 뭐 해?')를 사용하여 질문한다. '경험과 
연관시키기'는 책에 나온 그림이나 어휘를 아동의 경험과 관련지어 말해보도록 하여 책의 내용과 실제 생활을 연결하도록 촉진한다. 이후 성인은 아동이 산출한 발화를 '평가(E)'하여, 아동의 산출이 적절하지 않은 경우에 정확한 정보를 제공하여 아동의 발화를 수 정해주고, 아동의 산출이 적절한 경우, 아동의 발화 형태를 문법요 소나 의미적 자질을 보완하여 ‘확장/확대(E)'하여 들려준다(예: 아 동 ‘차', 성인 ‘그래, 이거는 빨간 소방차야'). 이후 성인은 ‘확장/확 대’하여 들려준 발화를 아동이 '반복(R)'하도록 한다.

훈련

본 연구의 중재 절차와 방법은 Whitehurst와 동료들(Whitehurst et al., 1994; Whitehurst \& Lonigan, 1998)의 PEER 전략의 틀을 근거로 수정하여 사용하였다. 원 PEER 전략에서는 촉진의 하위 기 법인 CROWD 기법을 일정한 순서나 빈도의 제한 없이 아동의 반 응 형태와 맥락에 따라 성인이 적절히 선택하여 사용하도록 제안 하였으나, 본 연구에서는 대상자 간 동일한 중재 조건을 만족시키 기 위하여 아동의 반응에 따라 일정한 체계적인 순서를 정하여 중 재하였다. 본 연구의 구체적 중재 절차는 다음과 같다(Table 2).

각 회기는 아동에게 책의 제목과 활동 순서를 설명하는 것으로 시작하였다. 첫 단계는 아동과 함께 그림책을 보면서 연구자가 처 음부터 끝까지 이야기를 들려주었다. 이후에 그림책을 다시 보면서 PEER 전략의 '촉진', '평가', ‘확장', '반복’을 사용하여 그림책의 각 장을 진행하였다. 촉진 단계에서는 우선 그림책 첫 장을 다시 보며 먼저 ‘회상하기' 기법을 사용하여 해당 책에서 주인공에게 무슨 일 이 일어났는지 질문을 하였다. 아동이 반응을 하지 않거나 관련 없 는 이야기를 하는 경우에는 '개방형 질문, '의문사 질문, '문장 완성 하기'의 순서로 좀 더 구체적인 단서를 제공하는 촉진 단계로 진행 하였다. 이야기의 연결에 방해가 되지 않도록 '경험과 연관시키기'

Table 2. Procedure of intervention

\begin{tabular}{|c|c|c|c|c|c|c|c|c|c|c|}
\hline Intro. & \multirow{2}{*}{\multicolumn{10}{|c|}{$\begin{array}{l}\text { Introduce title of the book and explain the activity to the child. } \\
\text { "Today, we'll read a book together. The title of the book is 'XX'." } \\
\text { "I'Ill tell you about the book first, then let's talk together about the book." } \\
\text { Read the book out loud while looking at each page together }\end{array}$}} \\
\hline First step & & & & & & & & & & \\
\hline $\begin{array}{c}\text { PEER pro- } \\
\text { cedures }\end{array}$ & $\begin{array}{l}P \\
r \\
o \\
m \\
p \\
t\end{array}$ & $\begin{array}{c}\text { Recall } \\
\vdots \\
\text { Open-ended } \\
\vdots \\
\text { Wh-Q } \\
\vdots \\
\text { Completion }\end{array}$ & $\rightarrow$ & $\begin{array}{l}E \\
v \\
a \\
l \\
u \\
a \\
t \\
e\end{array}$ & $\rightarrow$ & $\begin{array}{l}p \\
a \\
n \\
d\end{array}$ & $\rightarrow$ & $\begin{array}{l}R \\
e \\
p \\
e \\
a \\
t\end{array}$ & $\rightarrow$ & Distancing \\
\hline
\end{tabular}

질문은 각 책의 마지막 장에서만 사용하였다. 이 단계에서는 연구 자가 해당 책의 주요 사건과 아동의 경험을 연결하여 이야기를 산 출해보도록 하였다(예: 너도 조지처럼 한 적 있었어?). 아동이 촉 진 단계의 기법들에서 산출한 모든 반응에 대해서는 '평가', '확대', ‘반복’의 기법을 적용하였다. 훈련절차를 도식화하면 Table 2 와 같 다. 구체적인 중재 방법과 예시는 Appendix 1 에 제시하였다.

대화식 책 읽기는 동일한 그림책을 3 회 이상 반복해서 읽기를 권 고한다(Flynn, 2011; Whitehurst et al., 1994). 동일한 책을 반복적 으로 읽음으로써 아동이 전반적인 책의 내용과 새로운 어휘, 문장 및 담화적 표현에 익숙해지며, 이를 통해 문장 및 이야기 수준을 향 상시키는 장점이 있다고 제언한다. 본 연구에서도 총 5 권을 각각 3 회기 동안 연속적으로 중재에 사용하였다.

평가

평가는 매 회기 훈련 전에 실시하였고 모든 아동들에게 동일한 8 권의 책을 2 회씩 사용하였다. 순서효과를 통제하기 위하여 대상자 간에 제시 순서를 다르게 조절하였다. 매 평가에서 아동에게 2 권을 제시하고 그 중에서 아동이 원하는 책을 스스로 선정하도록 하였 다. 단, 이전 회기에서 선택한 책은 최소 2 주 이상의 간격을 두어 제 시하였다.

평가는 연구자와 대상아동이 그림책을 함께 보면서 미리 연구자 의 목소리로 녹음한 이야기를 들려준 후에 아동이 그림책을 보면서 회상 산출하도록 하였다. 연구자는 아동에게 이야기를 녹음해서 다른 사람에게 들려주자고 말하고 아동의 이야기를 녹음하였다. 아동이 자발적 개시를 못하는 경우에는 '어느 날 조지가' 와 같은 개시적 어구를 사용한 1 차 촉진을 제공하고, 이후에도 자발적인 산 출이 나타나지 않을 경우에는 개방형 질문(예: ‘이 그림에서 무슨 일 이 일어났니?')을 사용한 2차 촉진을 제공하였다. 아동의 이야기 산 출 상황에서 중재자는 2 단계의 촉진 이외에는 '응', ‘그렇구나', '그래 서?'와같은 반응만을 적절하게 제공하였다.

평가에 사용한 이야기 구성은 자료분석에서 설명하였다.

\section{유지 단계}

중재 종료 1 주 후에 대상아동들에게 3 회기 동안 평가과제를 실 시하였다.

\section{자료 분석}

모든 분석은 들려준 이야기와 관련된 발화만을 포함하였다. 이 야기 자료 분석 예는 Appendix 2에 제시하였다. 
대형구조

대형구조는 이야기 문법 총 산출점수 및 유형별 산출점수를 분 석하였다. 분석은 Petersen, Gillam, Spencer와 Gillam (2010)의 기 준에 근거하였다. 이야기 문법 유형은 등장인물, 시간. 장소, 계기사 건, 내적반응, 계획, 시도, 결과의 7 가지로 분류하였으며, 유형별로 산출수준에 따라 0-3점으로 평가하였다. 이야기 문법 분석기준은 Appendix 3에 제시하였다. 정확한 회상이 아니더라도 같은 의미의 내용을 표현한 경우나 구문적 오류 등은 분석에 포함하였다.

이야기 문법 총 산출점수

한 이야기에 2 개의 에피소드를 포함하고, 에피소드 당 7 가지 유 형을 모두 포함하여 아동이 한 회기에 얻을 수 있는 이야기 문법 총 점수의 범위는 0-42점이었다.

이야기 문법 하위 유형별 산출점수

이야기당 2 개의 에피소드와 이야기 문법 하위 유형별 빈도를 동 일하게 구성하고, 하위 유형별로 산출점수를 분석하였다. 따라서 회기별 각 유형의 산출 점수 범위는 0-3점으로 각 유형별로 얻을 수 있는 최대 점수는 6점이었다.

소형구조

소형구조는 이야기 산출성과 구문 복잡성 측면을 고려하여, Tunit 및 낱말 총 산출수, MLT-w (mean length of T-unit-word), 절 밀도, 종속절 유형별 산출률을 분석하였다. 이때 T-unit의 분석은 Kim과 Kim (2011)에 근거하였다. T-unit은 기본적으로 '주어+서술 어'의 주절로 이루어진 문장을 기본단위로, 주절에는 연결문이나 내포문이 포함되며, 한국어의 특성상 주절에서 주어가 생략된 경 우도 하나의 T-unit으로 분석하였다. 대등적 연결어미를 사용하고 선행절과 후행절이 의미적으로 대등한 경우나 종속적 연결어미를 사용하였더라도 단순히 절을 나열한 경우도 각 절을 하나의 T-unit 으로 분리하여 분석하였다.

(1) T-unit 총 수 및 낱말 총 수: 평가 시 아동이 산출한 T-unit 수 와 낱말 수를 각각 합산하였다.

(2) MLT-w: T-unit의 낱말 총수를 T-unit 총수로 나누어 산출하

Table 3. Mean of story grammar at each phase

\begin{tabular}{lcccll}
\hline \multirow{2}{*}{ Subject } & \multirow{2}{*}{ Baseline } & \multicolumn{3}{c}{ Experimental } & \\
\cline { 3 - 5 } & & Early & Middle & Late & \\
\hline A & 13.6 & 21.2 & 25 & 30 & 30.3 \\
B & 9.3 & 12 & 20 & 23.6 & 24 \\
C & 7.3 & 14 & 22.5 & 25.6 & 24 \\
\hline
\end{tabular}

였다.

(3) 절밀도: T-unit의 주절과 종속절의 총 수를 T-unit 총 수로 나 누어 산출하였다.

(4) 종속절 유형별 산출률: 각 종속절(부사절, 관형절, 명사절, 인 용절) 총수를 전체 종속절 수로 나누어 100 을 곱하였다.

\section{신뢰도}

아동별로 약 $20 \%$ 의 자료를 임의로 추출하여 연구자와 제 1 평가 자의 평가자 간 신뢰도를 측정하였다. 전사 신뢰도는 $98 \%$ 였으며, 종속변인별 신뢰도는 이야기 문법 점수 $98 \%$, MLT 96\%, 절밀도 97\%, 종속절 유형별 96\%, T-unit 수 99\%의 일치도를 나타내었다.

\section{연구 결과}

\section{대형구조 분석 결과}

이야기 문법 총 산출점수

전반적으로 세 아동 모두 이야기 문법 산출 점수가 중재가 진행 될수록 향상되었으며, 유지단계에도 중재 후반 수준이 지속되었다 (Table 3, Figure 1).

아동 $\mathrm{A}$ 는 세 아동 중 기초선 수준이 가장 높았으며, 중재 전반에 가장 큰 상승폭을 보였다. 중재 중반 초기 3회기 연속 하향이 나타

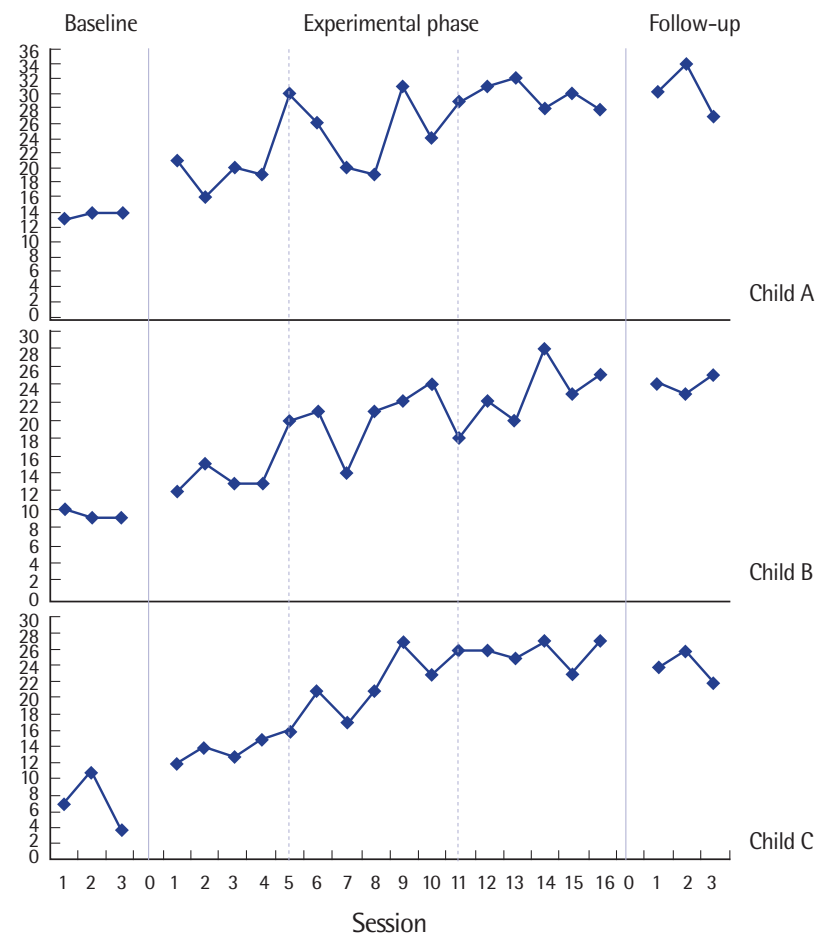

Figure 1. Story grammar score. 
나기도 하였으나, 이후 안정적인 상승을 보였으며, 전체적으로 상승 추세를 나타냈다. 기초선과 비교 시 중재 후반에 평균 점수가 약 17 점 증가하였다.

아동 $\mathrm{B}$ 는 중재 전반에서 비교적 안정적인 상승 추세를 나타냈으 며, 초반과 중반 사이에 가장 큰 상승 폭을 보였다. 기초선과 비교 시 중재 후반에 평균 점수가약 14 점 증가하였다.

아동 C는 세 아동들 중 가장 낮은 기초선 점수를 나타냈으나, 중 재 이후 가장 큰 상승 폭을 나타냈다. 중재 전반에 걸쳐 매우 안정적 인 상향 추세를 보였으며, 초반과 중반 사이에 가장 큰 상승 폭을 나 타냈다. 기초선과 비교 시 중재 후반에 평균 점수가 약 18 점 증가하 였다.

\section{이야기문법 하위 유형별 점수}

전반적으로 세 아동 모두 이야기 문법 하위 유형별 산출 점수가 중재가 진행될수록 향상되었으며, 유지단계에도 중재 후반 수준이 지속되었다(Table 4). 세 아동들 모두 기초선에서 산출하지 않았던 하위 유형들을 중재 이후에 모두 산출하였다.

아동 $\mathrm{A}$ 는 특히 계기사건, 계획, 시도, 결과에서 중재 후반에 기초 선 대비 3점 이상의 증가를 보였다. 기초선에서 나타나지 않았던 계 획은 중재 후반에는 평균 3점을 나타냈다. 등장인물, 시간/장소, 내 적반응은 중재 초기부터 증가를 나타내었으며, 중재 후반에는 모 두 기초선과 중재 전반 대비 향상된 점수를 나타냈다.

Table 4. Mean of story grammar properties at each phrase

\begin{tabular}{|c|c|c|c|c|c|c|}
\hline \multirow{2}{*}{ Subject } & \multirow{2}{*}{ Phase var. } & \multirow{2}{*}{ Baseline } & \multicolumn{3}{|c|}{ Experimental } & \multirow{2}{*}{$\begin{array}{c}\text { Follow- } \\
\text { up }\end{array}$} \\
\hline & & & Early & Middle & Late & \\
\hline \multirow[t]{7}{*}{ A } & Character & 3 & 4.2 & 5 & 5.2 & 5.3 \\
\hline & Time/place & 3.3 & 3.4 & 3 & 4.6 & 3 \\
\hline & Initiating event & 1.6 & 3.6 & 3.8 & 5 & 5.6 \\
\hline & Internal response & 1.6 & 2 & 3.1 & 2.2 & 2.6 \\
\hline & Plan & 0 & 1.6 & 1.8 & 3 & 2.3 \\
\hline & Attempt & 2.3 & 3 & 4.1 & 5.4 & 5.3 \\
\hline & Consequence & 1.6 & 3.4 & 4.3 & 4.8 & 5.6 \\
\hline \multirow[t]{7}{*}{$B$} & Character & 3.6 & 3.4 & 4.6 & 4.2 & 4.6 \\
\hline & Time/place & 2 & 3 & 4.3 & 3.4 & 3.6 \\
\hline & Initiating event & .6 & 1.6 & 2.8 & 5 & 5 \\
\hline & Internal response & 0 & .4 & .6 & 1.6 & 0 \\
\hline & Plan & 0 & .4 & .3 & 1.2 & 1.3 \\
\hline & Attempt & 1 & 1.6 & 4 & 4.2 & 4.6 \\
\hline & Consequence & 2 & 3.4 & 3.5 & 4.4 & 5 \\
\hline \multirow[t]{7}{*}{ C } & Character & 1.6 & 4 & 4.3 & 5.6 & 4.6 \\
\hline & Time/place & 1.6 & 2.6 & 3.8 & 3.8 & 2.6 \\
\hline & Initiating event & 1.6 & 2.2 & 3.8 & 5.2 & 5 \\
\hline & Internal response & .3 & 1 & 1.3 & 1.6 & 1.6 \\
\hline & Plan & 0 & .8 & 2.1 & 1 & 0 \\
\hline & Attempt & 1.6 & 1.8 & 3.6 & 4.6 & 4.6 \\
\hline & Consequence & .6 & 2.2 & 3.5 & 4.8 & 5 \\
\hline
\end{tabular}

아동 $\mathrm{B}$ 는 계기사건과 시도 유형이 중재 후반에 기초선 대비 가장 큰 향상을 보였으며, 특히 계기 사건은 중재 후반에서 급진적인 향 상을 나타냈다. 결과도 중재 후반에 기초선 대비 2 배 이상의 점수 증가를 보였다. 특히 기초선에서 나타나지 않았던 '내적반응', '계획' 이 중재 초기부터 간헐적으로 나타나 후반에는 평균 1.6 의 점수를 나타냈다. 등장인물과 시간장소도 중재 중, 후반까지는 기초선 대 비 상당한 향상을 보였다.

아동 C는 등장인물, 계기사건, 시도, 결과가 중재 후반에 기초선 대비 3점 이상의 향상을 보였다. 기초선에서 거의 산출되지 않았던 계획, 내적반응, 결과를 포함하여 대부분의 하위 유형들이 기초선 과 중재 전, 중, 후반에 걸쳐 기복 없이 지속적으로 향상되었다.

\section{소형구조 분석 결과}

T-unit 총 수, 낱말 총 수 및 MLT-w 분석 결과

전반적으로 세 아동 모두 T-unit 총 수와 낱말 총 수가 증가하는 것으로 나타났고 증가된 T-unit의 총 수와 낱말 총 수, MLT-w가 유 지 단계까지 중재 후반의 수준이 지속되는 것으로 나타내어 산출 적인 부분에서는 큰 향상을 나타내었다(Table 5, Figure 2).

아동 A의 T-unit 총 수는 중재 초반과 중재 중반까지 향상을 보 이다 중재 후반에는 증가된 T-unit 수가 지속되는 것으로 나타났 다. 기초선과 비교 시 중재 후반에 T-unit 총 수가 약 4 개 증가하였 다. 낱말 총 수의 경우 기초선 단계와 비교 시 2 배 가량의 낱말 수가 증가되었고, 중재 전반에서 중재 후반, 유지 단계까지 지속적으로 낱말 총 수가 큰 향상을 나타내었다. MLT-w의 경우 중재 전반에 걸 쳐 꾸준히 증가하는 것으로 나타났고, 기초선과 비교 시 중재 후반 에는 MLT-w가 3 개 증가하였다.

아동 B의 T-unit 총 수는 중재 초반과 중재 중반까지 상향 추세 를 보이다 중재 후반에서는 증가된 T-unit 수가 지속되는 것으로 나 타났다. 기초선과 비교 시 중재 후반에 T-unit 총 수가 약 6개 증가

Table 5. Mean scores of T-unit, TNW, MLT-w at each phase

\begin{tabular}{|c|c|c|c|c|c|c|}
\hline \multirow{2}{*}{ Subject } & \multirow{2}{*}{ Phase var. } & \multirow{2}{*}{ Baseline } & \multicolumn{3}{|c|}{ Experimental } & \multirow{2}{*}{ Follow-up } \\
\hline & & & Early & Middle & Late & \\
\hline$A$ & $\begin{array}{l}\text { T-unit } \\
\text { TNW } \\
\text { MLT-w }\end{array}$ & $\begin{array}{r}8.6 \\
57.6 \\
6.8\end{array}$ & $\begin{array}{c}13.4 \\
113 \\
8.4\end{array}$ & $\begin{array}{r}14 \\
124.3 \\
8.6\end{array}$ & $\begin{array}{c}13 \\
138.6 \\
10\end{array}$ & $\begin{array}{c}14 \\
154.3 \\
11\end{array}$ \\
\hline B & $\begin{array}{l}\text { T-unit } \\
\text { TNW } \\
\text { MLT-w }\end{array}$ & $\begin{array}{c}4.3 \\
36 \\
8.3\end{array}$ & $\begin{array}{r}7.4 \\
62.6 \\
8.6\end{array}$ & $\begin{array}{l}10 \\
86.6 \\
8.5\end{array}$ & $\begin{array}{c}10 \\
95 \\
9.8\end{array}$ & $\begin{array}{r}9.6 \\
87.6 \\
9.3\end{array}$ \\
\hline C & $\begin{array}{l}\text { T-unit } \\
\text { TNW } \\
\text { MLT-w }\end{array}$ & $\begin{array}{c}5.6 \\
39 \\
6.6\end{array}$ & $\begin{array}{r}8.6 \\
71.8 \\
8.4\end{array}$ & $\begin{array}{r}11.3 \\
86.6 \\
8.3\end{array}$ & $\begin{array}{c}13 \\
95 \\
8.4\end{array}$ & $\begin{array}{r}13.6 \\
87.6 \\
7.6\end{array}$ \\
\hline
\end{tabular}

TNW= total number of words; MLT-W= mean length of T-unit-word. 

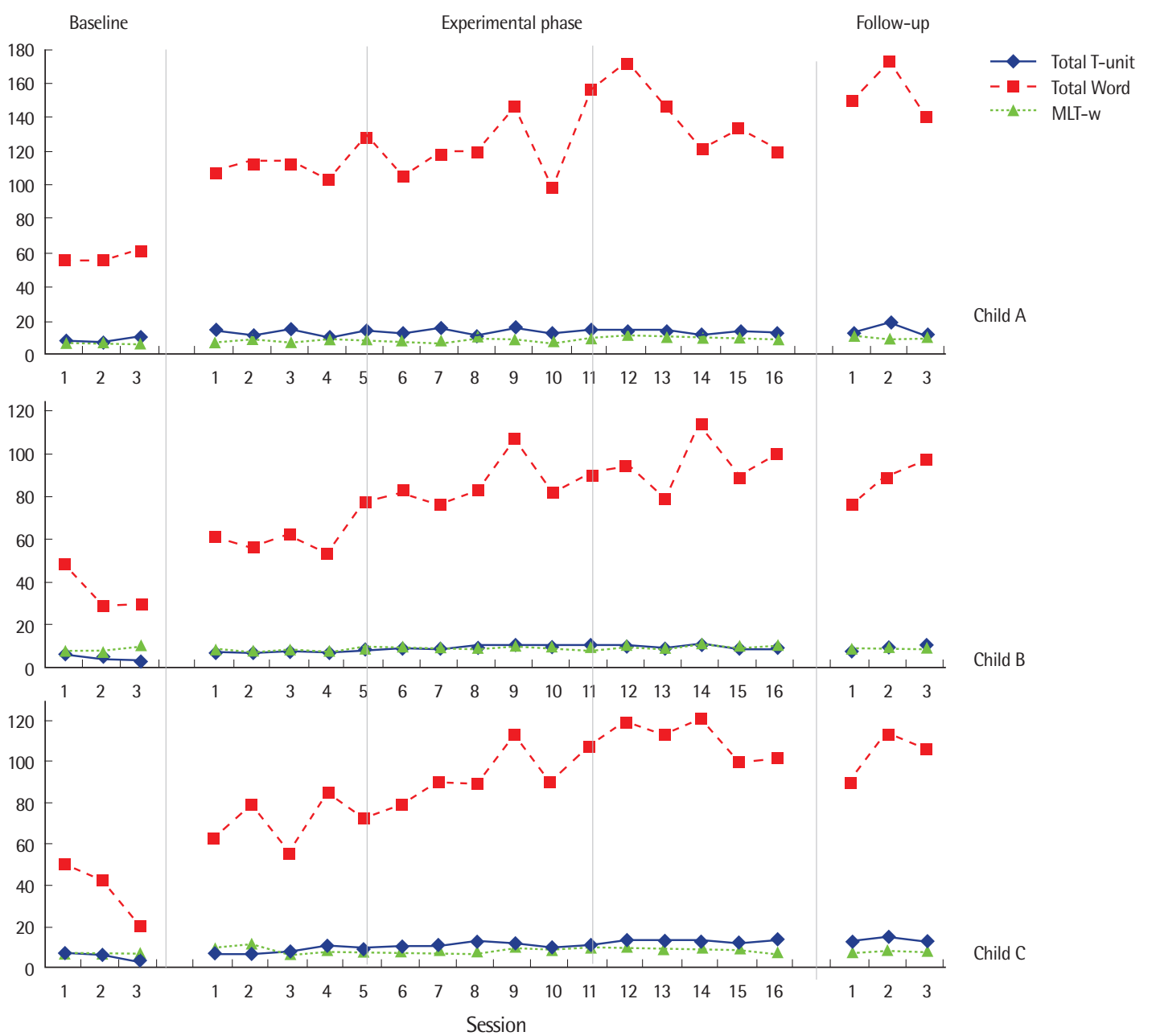

Figure 2. Scores of T-unit, total number of words (TNW), mean length of T-unit-word (MLT-w).

하였다. 낱말 총 수의 경우 기초선과 비교 시 중재 중반까지 20개 이 상의 낱말 수가 증가하였고 중재 후반에 걸쳐 지속적인 상승을 나 타내었다. MLT-w의 경우 점진적인 향상을 나타내었다.

아동 C의 T-unit 총 수는 기초선과 비교 시 중재 후반에 T-unit 총 수가 약 8 개 증가하였다. 낱말 총 수의 경우 기초선과 비교 시 중 재 전반에 약 30 개의 낱말 수가 증가하였고, 중재 후반까지 꾸준히 낱말 총 수가 증가하는 것으로 나타내었다. MLT-w의 경우 중재 전 반에 걸쳐 상향 추세를 나타내었고, 기초선과 비교 시 중재 후반에 MLT-w가 평균 2개 증가하였다.

\section{절밀도 분석 결과}

세 아동 모두 향상 폭이 크진 않았으나, 중재 후반에는 기초선 대 비 향상된 절밀도를 보였다. 구간별 평균을 보면, 기초선 대비하여 아동 $\mathrm{A}$ 는 중재 중반, 아동 $\mathrm{B}$ 는 중재 후반, 아동 $\mathrm{C}$ 는 중재 초반부터 향상을 나타냈다(Table 6).

\section{종속절 유형별 산출률 분석 결과}

전반적으로 세 아동 모두 중재가 진행될수록 종속절 유형이 다 양해지는 특성을 보였다. 기초선 및 중재 전반에 걸쳐서 부사절 유 형의 산출률이 다른 유형에 비해 가장 높았지만, 세 아동 모두 기초 선과 중재 초반에 나타나지 않았던 종속절 유형들이 중재 후반까 지는 모두 산출되었다(Table 6).

아동 $\mathrm{A}$ 는 기초선 단계에서 인용절을 제외한 부사절, 관형절, 명 사절이 모두 산출되었으나 부사절이 $78 \%$ 로 대부분을 차지하였다. 중재 전반에 인용절의 산출이 나타났으며, 중재 후반에는 부사절 $55 \%$, 관형절 $12 \%$, 명사절 $23 \%$, 인용절 $10 \%$ 로 부사절의 비율이 낮 아지고, 상당히 고른 유형별 산출이 나타났다.

아동 $\mathrm{B}$ 는 기초선에서는 부사절 외에 다른 유형들이 산출되지 않 았으나, 중재 중반부터 관형절과 명사절의 산출이 각각 $13 \%, 11 \%$ 로 나타났으며, 후반에는 인용절도 산출되었다. 중재 후반에는 부사 절 $59 \%$, 관형절 $13 \%$, 명사절 $15 \%$, 인용절 $13 \%$ 로 역시 모든 유형이 
Table 6. Mean score of clausal density and mean percentage of subordinate clauses at each phase

\begin{tabular}{|c|c|c|c|c|c|c|c|}
\hline \multirow{2}{*}{ Subject } & \multirow{2}{*}{ Phase var. } & & \multirow{2}{*}{ Baseline } & \multicolumn{3}{|c|}{ Experimental } & \multirow{2}{*}{ Follow-up } \\
\hline & & & & Early & Middle & Late & \\
\hline \multirow[t]{6}{*}{ A } & Clausal density & & 1.5 & 1.5 & 1.7 & 1.7 & 1.6 \\
\hline & Subject C (\%) & Adverbial & 78 & 63 & 57 & 55 & 50 \\
\hline & & Adnominal & 8 & 2 & 18 & 12 & 15 \\
\hline & & Noun & 14 & 32 & 21 & 23 & 23 \\
\hline & & Quotative & 0 & 3 & 4 & 10 & 13 \\
\hline & & Sum & 100 & 100 & 100 & 100 & 100 \\
\hline \multirow[t]{6}{*}{ B } & Clausal density & & 1.3 & 1.2 & 1.3 & 1.6 & 1.5 \\
\hline & Subject C (\%) & Adverbial & 100 & 96 & 76 & 59 & 45 \\
\hline & & Adnominal & 0 & 0 & 13 & 13 & 24 \\
\hline & & Noun & 0 & 4 & 11 & 15 & 24 \\
\hline & & Quotative & 0 & 0 & 0 & 13 & 7 \\
\hline & & Sum & 100 & 100 & 100 & 100 & 100 \\
\hline \multirow[t]{6}{*}{ C } & Clausal density & & 1.2 & 1.5 & 1.6 & 1.6 & 1.4 \\
\hline & Subject C (\%) & Adverbial & 89 & 70 & 64 & 66 & 69 \\
\hline & & Adnominal & 0 & 20 & 8 & 7 & 17 \\
\hline & & Noun & 0 & 7 & 15 & 7 & 3 \\
\hline & & Quotative & 11 & 3 & 13 & 20 & 11 \\
\hline & & Sum & 100 & 100 & 100 & 100 & 100 \\
\hline
\end{tabular}

산출되었고, 상당히 고른 유형별 산출을 보였다.

아동 $\mathrm{C}$ 는 기초선에서는 부사절이 대부분이었으나 다른 아동들 과는 다르게 기초선부터 $11 \%$ 가량의 인용절을 산출하였다. 중재 전 반에 관형절과 명사절이 산출되었으며, 중재 후반에 부사절 $66 \%$, 관형절 $7 \%$, 명사절 $7 \%$, 인용절 $24 \%$ 로 다양성이 증가하였으나, 상 대적으로 인용절 산출률이 높았다.

\section{논의 및 결론}

본 연구는 언어발달지체를 가진 6-7세 아동 3명을 대상으로 '대 화식 책 읽기' 중재가 아동의 이야기 회상 산출의 이야기 문법과 구 문 산출 능력에 미치는 효과를 검증하였다. 본 연구를 통한 결과 및 논의는 다음과 같다.

첫째, 대형구조 분석의 이야기 문법 총점에서 세 아동 모두 중재 를 통한 향상을 나타내었으며, 중재 종료 후에도 향상된 수준이 유 지되었다. 이야기 문법 총 점수의 향상은 아동들이 단순히 그림을 묘사한 것이 아니라 이야기 속 사건의 원인과 그로 인한 주인공의 반응과 결과를 연결하여 하나의 일화로 산출하는 이야기 구성 능력 이 향상되었음을 의미한다. 이야기 문법의 하위 유형들도 세 아동 모두 산출률과다양성 측면에서 향상을 보였다. 대상자들은 공통적 으로 '등장인물, '계기사건', '시도', '결과'의 산출에서 큰 증가를 보였 다. 특히 중재 전에 거의 산출되지 않았던 ‘내적반응'과 '계획’이 중재 이후지속적으로 산출되었다는 점은 중요한 효과라고 할 수 있다.

언어 학습에 결함이 있는 아동들은 특히 이야기 문법 측면에서
하위 유형별 산출량이나 다양성에서 일반아동에 비해 낮은 산출 을 보인다(Kim \& Pae, 2004; Stein \& Glenn, 1979). 일반 발달에서 가장 늦게 발달하는 유형인 내적반응은 언어발달 결함이 있는 학 령기 아동들이 일반 아동들과 가장 큰 차이를 나타내는 유형 중 하 나이다(Ripich \& Griffith, 1988). 이러한 점들을 고려할 때 본 연구 의 대형구조에 대한 효과는 상당한 의미를 갖는다. Chae (1995)는 5 세 일반 아동들이 이야기 내용만을 중심으로 한 분석적 접근보다 아동의 경험과 연결한 경험적 접근에서 유의하게 높은 내적반응 산출빈도, 이야기 길이, 내용 구성을 나타냈다고 보고하였다. 이는 아동의 배경지식이 이야기 산출 능력 향상에 미치는 효과를 시사 한다. 본 연구의 중재 전략 중 '경험과 연관시키기' 단계의 이야기 문 법 발달 촉진에 대한 효과를 지지하는 결과라 할 수 있다.

PEER 전략의 그림책과 회상산출 맥락에서 지속적인 성인의 피 드백 사용은 아동들이 이야기 전반을 이해하고 주요 내용을 연계 시켜 산출하는데 큰 효과가 있는 것으로 보인다. Morrow (1986)는 성인과 함께 이야기를 듣고 회상 산출 훈련을 한 아동들의 이야기 문법 산출능력이 그렇지 않은 집단에 비해 유의하게 높았다고 보 고하였다. 또한 가족이나 교사들이 아동과 책을 읽으면서 대화하 는 형식을 사용한 경우 후일 아동들의 이야기와 문해 능력의 발달 에 큰 효과가 있었다는 연구들도 보고되었다(Crain-Thoreson \& Dale, 1999; Lecci et al., 1994) 이러한 결과들은 아동들의 이야기 문 법 능력 향상에 대한 PEER 전략의 효과성을 지지한다.

둘째, 대화식 책 읽기 중재가 아동의 소형구조에 미치는 효과를 살펴본 결과, 세 아동 모두 문장 발화의 산출량과 문장을 구성하는 
구문능력이 크게 향상된 것으로 나타났다.

구체적으로 변인들의 변화를 살펴보면, 세 아동 모두 T-unit 총 점수의 증가를 나타냈다. 아동 $\mathrm{A}$ 는 중재 초반에 T-unit의 산출이 크게 증가한 후 중재 기간 동안 유사한 수준을 유지하였다. 그러나 양적으로는 중재 중반 이후에 큰 변화가 없었지만 질적으로는 긍정 적인 효과를 나타냈다. 아동 $\mathrm{A}$ 는 기초선 단계와 중재 초반에서는 산출량에 비해 이야기와 관련된 내용이 적었던 반면, 중반 이후에 는 관련 발화가 증가하는 긍정적인 변화를 보였다. 아동 $\mathrm{B}$ 와 $\mathrm{C}$ 는 기초선 단계에서 중재자가 들려준 이야기의 양에 비해 회상 산출의 양이 매우 적었으나, 중재 이후 아동 $\mathrm{B}$ 는 점진적인 향상을, 아동 C 는 중반 이후 급진적인 향상을 나타냈다. 세 아동 모두 이야기 회상 산출의 양적인 향상과 동시에 이야기 관련 발화의 산출량이 향상 되는 긍정적인 결과를 나타냈다. 실질적으로 아동들은 기초선 자 료를 수집할 때 평가 시에 들은 이야기에 대한 정확한 요점을 찾지 못하고 단순히 그림만 묘사한다거나 주변적인 상황만 이야기를 했 지만 중재가 진행되면서 이야기 흐름에 초점을 둔 이야기 산출이 가능하였다.

T-unit당 평균 낱말 길이는 중재 회기별로 보면 변동 폭이 간혹 크게 나타나기도 했지만, 중재 구간별로 세 아동 모두 꾸준한 상승 을 나타냈다. 이는 한 문장을 좀 더 길게 형성할 수 있는 능력이 향 상되었다는 것을 보여주는 것으로, 중재가 문장 내 언어 산출성에 도 효과가 있음을 나타낸다. T-unit당 평균 낱말 길이는 연령에 따 른 증가를 나타내는 구문 발달의 효율적인 지표 중 하나이다(Loban, 1976; Nippold, Hesketh, Duthie, \& Mansfield, 2005). 본 연구 에서 T-unit당 평균 낱말 길이는 중재 16 회기 동안 아동별로 기초 선 대비 평균적으로 약 2 낱말의 향상을 보였다. 짧은 기간 동안 나 타난 이러한 급속한 향상은 중재에서 사용한 중재 전략이 문장 발 화의 길이를 증가시키는데 상당한 효과가 있음을 시사한다.

절밀도 또한 중재를 통한 증가가 나타났다. 절밀도의 특성상 단 기간 양적으로 큰 상승을 기대하기는 어렵다. 그러나 대상자들이 나타낸 종속절 유형별 산출의 변화를 함께 고려하면 대화식 책 읽 기 전략의 구문에 대한 확실한 효과를 보여준다. 대상자 모두 기초 선 단계에서는 부사절이 대부분이었지만 중재가 진행됨에 따라 기 초선 단계에서 산출되지 않았거나 산출률이 낮았던 관형절, 명사 절, 인용절 등의 유형들이 산출되었다. 특히 다양성의 증가뿐만 아 니라 중재 후반에는 유형들 간 산출률이 상당히 고른 분포를 나타 냈다. 이러한 변화들은 주로 종속적 연결문의 형태로 산출했던 복 문들을 다양한 내포문을 포함한 복문으로 산출할 수 있는 능력이 향상되었음을 보여준다. 5 세 일반 아동들에게 대화식 책 읽기를 실 시한 Lever와 Sénéchal (2011)도 구문의 복잡성 증가를 보고하였
다. 대화식 책 읽기는 책을 읽는 동안 아동에게 적극적인 화자의 역 할을 부여함으로써 특히 표현언어발달의 촉진에 효과를 보여왔다 (Whitehurst \& Lonigan, 1998). 성인의 질문을 통해 문장 형성의 단 서를 제공하고, 확장과 확대 기법을 통해 좀 더 발달된 문장 형태의 모델링을 제공하고 이를 반복 산출하도록 하는 과정이 특히 구문 발달을 촉진하는 데 효과적으로 보인다. Valdez-Menchaca와 Whitehurst (1992)는 비록 2세 아동들을 대상으로 하였으나 6주 동안 대 화식 책 읽기 중재를 실시한 집단이 다른 대체 활동을 진행한 집단 에 비해 문장의 복잡성과 명사와 술어의 다양성이 유의하게 높게 나타났음을 보고한 바 있다. 이 또한 책을 매개로 한 성인과의 대화 식 이야기 회상 산출 훈련이 구문의 발달에 미치는 긍정적 효과를 입증한다.

이상에서 논의한 바와 같이 본 연구 결과들은 주로 2-3세 어린 아동들의 낱말이나 문장의 이해 및 산출 촉진에 사용되었던 대화 식 책 읽기 중재 활동이 그보다 나이 든 아동들의 이야기 담화 발달 의 촉진에도 효과가 있었다는 선행연구 결과(Lever \& Sénéchal, 2011)를 지지할 뿐만 아니라, 언어발달지체를 가진 아동들의 이야 기 산출 능력에도 효과가 있음을 보여 주었다.

이야기 회상 산출은 언어장애 아동들의 중재에서 가장 중요한 영역 중 하나이지만 효과적인 중재 방법을 찾기가 쉽지 않다. 담화 산출에 필요한 메타언어적인 능력과 인지 능력에 결함이 있는 아 동들에게는 상위 언어처리를 좀 더 쉽게 할 수 있는 충분한 단서와 연습이 필요하다. 그림책을 사용한 대화식 책 읽기 중재방법은 아 동이 점진적으로 청자에서 화자가 되어가도록 성인의 체계적인 촉 진과상호작용을 전략을 사용한다. 또한 그림이라는 단서를 제공함 으로써 언어발달에 결함을 가진 아동들이 이야기 회상 산출에서 겪는 기억과 언어적 처리과정의 어려움을 경감시킬 수 있는 발판을 제공한다. 그림과 단계적인 질문을 사용한 쉽고 체계적인 단서 제 공, 대화를 통한 모델링, 그리고 충분한 산출 연습의 기회가 제공되 는 전략이 언어장애 아동들의 중재에 효과적인 방법이 될 수 있다.

본 연구는 학령전기 후반이나 학령기 아동들에게 적용할 수 있 는 이야기 중재에 대한 임상 전략을 제시했다는 점에서 의의가 있 다. 적은 대상자 수나 평가 책의 반복 사용을 통한 학습효과 등이 연구의 제한점이 될 수 있다. 다수의 대상자들을 포함한 사전-사후 평가 방법의 사용이나 부모 훈련을 통한 중재 효과 검증 등이 본 연 구의 후속연구로 필요하겠다.

\section{REFERENCES}

Beals, D. E. (2001). Eating and reading: links between family conversations 
with preschoolers and later language and literacy. In D. K. Dickinson \& P. O. Tabors (Eds.), Beginning literacy with language: young children learning at home and school (pp. 75-92). Baltimore, MD: Paul H. Brookes Publishing.

Bishop, D. V. M., \& Edmundson, A. (1987). Language-impaired 4-year-olds: distinguishing transient from persistent impairment. Journal of Speech and Hearing Disorders, 52, 156-173.

Bishop, D. V., \& Adams, C. (1992). Comprehension problems in children with specific language impairment literal and inferential meaning. Journal of Speech, Language, and Hearing Research, 35, 119-129.

Chae, J. O. (1995). Effects on two contrasting approaches of storybook reading on children's response to literature (Doctoral dissertation). Ewha Womans University, Seoul, Korea.

Cheon, S. H., \& Kim, J. M. (2007). The effects of language intervention based on story mapping on story comprehension and recall in children with mental retardation. Korean Journal of Communication Disorders, 12, 429-446.

Crain-Thoreson, C., \& Dale, P. S. (1999). Enhancing linguistic performance: parents and teachers as book reading partners for children with language delays. Topics in Early Childhood Special Education, 19, 28-39.

Flynn, K. S. (2011). Developing children's oral language skills through dialogic reading guidelines for implementation. Teaching Exceptional Children, 44, 8-16.

Kim, J. S., \& Kim, J. M. (2011). Characteristics of syntactic ability of schoolage children and adolescents in expository and narrative tasks. Korean Journal of Communication Disorders, 16, 540-558.

Kim, Y. J., \& Pae, S. (2004). Narrative abilities of Korean children with and without specific language impairment. Korean Journal of Developmental Psychology, 17, 41-58.

Kwak, K. C., Oh, S. W., \& Kim, C. T. (2011). Korean-Wechsler Intelligence Scale for Children-IV (K-WISC-IV). Seoul: Hakjisa.

Lecci, L., Karoly, P., Briggs, C., \& Kuhn, K. (1994). Specificity and generality of motivational components in depression: a personal projects analysis. Journal of Abnormal Psychology, 103, 404-408.

Lee, M. H., \& Kim, M. S. (2004). A dialogic picture book reading program: effects on teacher-toddler interactions and on toddler language. Korean Journal of Child Studies, 25, 41-57.

Lever, R., \& Sénéchal, M. (2011). Discussing stories: on how a dialogic reading intervention improves kindergartners' oral narrative construction. Journal of Experimental Child Psychology, 108, 1-24.

Liles, B. Z., Duffy, R. J., Merritt, D. D., \& Purcell, S. L. (1995). Measurement of narrative discourse ability in children with language disorders. Journal of Speech, Language, and Hearing Research, 38, 415-425.

Loban, W. (1976). Language development: kindergarten through grade twelve. Urbana, IL: National Council of Teachers of English.

Mandler, J. M. (1978). A code in the node: the use of a story schema in retrieval. Discourse Processes, 1, 14-35.

Merritt, D. D., \& Liles, B. Z. (1987). Story grammar ability in children with and without language disorder: story generation, story retelling, and story comprehension. Journal of Speech, Language, and Hearing Research, 30, 539-552.

Montague, M., Maddux, C. D., \& Dereshiwsky, M. I. (1990). Story grammar and comprehension and production of narrative prose by students with learning disabilities. Journal of Learning Disabilities, 23, 190-197.

Morrow, L. M. (1985). Retelling stories: a strategy for improving young children's comprehension, concept of story structure, and oral language complexity. Elementary School Journal, 85, 647-661.

Morrow, L. M. (1986). Effects of structural guidance in story retelling on children's dictation of original stories. Journal of Literacy Research, 18, 135-152.

Naremore, R. C., Densmore, A. E., \& Harman, D. R. (1995). Language intervention with school-aged children: conversation, narrative, and text. San Diego, CA: Singular Publishing Group.

Ninio, A. (1980). Picture-book reading in mother-infant dyads belonging to two subgroups in Israel. Child Development, 51, 587-590.

Nippold, M. A., Hesketh, L. J., Duthie, J. K., \& Mansfield, T. C. (2005). Conversational versus expository discoursea study of syntactic development in children, adolescents, and adults. Journal of Speech, Language, and Hearing Research, 48, 1048-1064.

Oh, Y. S., Kim, J. M., \& Lee, S. H. (2008). The effect of dialogic reading program for parents of children with developmental language delays. Korean Journal of Early Childhood Special Education, 8, 139-154.

Pae, S., \& Kwon, Y. (2006). Three measures of narrative discourse ability for Korea school-aged children in a story-retelling task. Korean Journal of Communication Disorder, 11, 72-89.

Pae, S., Lim, S. S., \& Lee, J. (2000). Test of problem solving (TOPS). Seoul: Seoul Community Rehabilitation Center.

Pae, S., Lim, S. S., Lee, J., \& Chang, H. S. (2004). Korea sentence comprehension test (KOSECT). Seoul: Seoul Community Rehabilitation Center.

Page, J. L., \& Stewart, S. R. (1985). Story grammar skills in school-age children. Topics in Language Disorders, 5, 16-30.

Park, C. H., \& Kim, M. S. (2010). The longitudinal effects of on early story- 
book reading intervention program on the improvement of first graders' language abilities in low-income families. Korean Journal of Child Studies, 31, 117-138.

Petersen, D. B., Gillam, S. L., Spencer, T., \& Gillam, R. B. (2010). The effects of literate narrative intervention on children with neurologically based language impairments: an early stage study. Journal of Speech, Language, and Hearing Research, 53, 961-981.

Rey, M., \& Rey, H. A. (1994). Curious George goes to the hospital. Boston, MA: Houghton Mifflin Company.

Rey, M., \& Rey, H. A. (1998a). Curious George and bunny. Boston, MA: Houghton Mifflin Company.

Rey, M., \& Rey, H. A. (1998b). Curious George in the snow. Boston, MA: Houghton Mifflin Company.

Rey, M., \& Rey, H. A. (1998c). Curious George goes to a movie. Boston, MA: Houghton Mifflin Company.

Rey, M., \& Rey, H. A. (1998d). Curious George goes to a chocolate factory. Boston, MA: Houghton Mifflin Company.

Rey, M., \& Rey, H. A. (1998e). Curious George and the puppies. Boston, MA: Houghton Mifflin Company.

Rey, M., \& Rey, H. A. (1999). Curious George goes camping. Boston, MA: Houghton Mifflin Company.

Rey, M., \& Rey, H. A. (2001a). Curious George goes fishing. Boston, MA: Houghton Mifflin Company.

Rey, M., \& Rey, H. A. (2001b). Curious George and the rocket. Boston, MA: Houghton Mifflin Company.

Rey, M., \& Rey, H. A. (2002a). Curious George visits a toy store. Boston, MA: Houghton Mifflin Company.

Rey, M., \& Rey, H. A. (2002b). Curious George takes a train. Boston, MA: Houghton Mifflin Company.

Rey, M., \& Rey, H. A. (2004). Curious George and the firefighters. Boston, MA: Houghton Mifflin Company.
Rey, M., \& Rey, H. A. (2005). Curious George first day of school. Boston, MA: Houghton Mifflin Company.

Rey, M., \& Rey, H. A. (2006). Curious George dinosaur discovery. Boston, MA: Houghton Mifflin Company.

Ripich, D. N., \& Griffith, P. L. (1988). Narrative abilities of children with learning disabilities and nondisabled children: story structure, cohesion, and propositions. Journal of Learning Disabilities, 21, 165-173.

Stein, N. L., \& Glenn, C. G. (1979). An analysis of story comprehension in elementary school children: a test of a schema. In R. O. Freedle (Ed.), New directions in discourse processing (pp. 1-68). Norwood, NJ: Ablex Publishing.

Valdez-Menchaca, M. C., \& Whitehurst, G. J. (1992). Accelerating language development through picture book reading: a systematic extension to Mexican day care. Developmental Psychology, 28, 1106-1114.

Westby, C. E., Van Dongen, R., \& Maggart, Z. (1989). Assessing narrative competence. Seminars in Speech and Language, 10, 63-76.

Whitehurst, G. J., \& Lonigan, C. J. (1998). Child development and emergent literacy. Child Development, 69, 848-872.

Whitehurst, G. J., Arnold, D. S., Epstein, J. N., Angell, A. L., Smith, M., \& Fischel, J. E. (1994). A picture book reading intervention in day care and home for children from low-income families. Developmental Psychology, 30, 679689.

Whitehurst, G. J., Falco, F. L., Lonigan, C. J., Fischel, J. E., DeBaryshe, B. D., Valdez-Menchaca, M. C., ..., \& Caulfield, M. (1988). Accelerating language development through picture book reading. Developmental Psychology, 24, 552-559.

Zevenbergen, A. A., \& Whitehurst, G. J. (2003). Dialogic reading: a shared picture book reading intervention for preschoolers. In S. A. Stahl, A. Van Kleeck, \& E. B. Bauer (Eds.), On reading books to children: parents and teachers (pp. 117-200). Mahwah, NJ: Lawrence Erlbaum Associates. 
Appendix 1. PEER 전략 방법 및 예시

\begin{tabular}{|c|c|c|c|}
\hline 절차 & & 방법 & 예 \\
\hline \multirow[t]{5}{*}{ 촉진(Prompt) } & 문장완성하기(Completion) & $\begin{array}{l}\text { 그림책을 보면서 연구자가 문장의 처음을 말하고 } \\
\text { 중간에 억양변화와 2-3초간 멈춤(pause)을 사용 } \\
\text { 하여 아동이 어휘/구를 채워 말하도록 함 }\end{array}$ & -조지는 물고기를 잡으려고 (pause)에 갔어요. \\
\hline & 회상하기(Recall) & $\begin{array}{l}\text { 이미 읽었던 이야기의 전반적인 내용이나 상황과 } \\
\text { 관련하여 내용을 질문 }\end{array}$ & - 여기에서 조지에게 무슨 일이 있었지? \\
\hline & 개방형 질문(Open-ended) & $\begin{array}{l}\text { 책의 그림을 중심으로 그림에 나와 있는 상황이나 } \\
\text { 사건에 대해 질문 }\end{array}$ & - 이 그림에서 무슨 일이 일어나고 있어? \\
\hline & 의문사 질문(Wh-question) & 그림을 손으로 가리키며 사물/행동에 대해 질문 & $\begin{array}{l}\text { - 앤 누구야? } \\
\text { - 이것은 뭐야? }\end{array}$ \\
\hline & $\begin{array}{l}\text { 경험과 연관시키기 } \\
\text { (Distancing) }\end{array}$ & $\begin{array}{l}\text { 책의 그림이나 이야기에서 나온 단어와 관련된 아 } \\
\text { 동의 경험에 대해 질문 }\end{array}$ & - 너도 조지처럼 물고기를 잡아 본적 있어? \\
\hline 평가(Evaluate) & & $\begin{array}{l}\text { 촉진에 대한 아동의 반응을 평가하여 중재자가 추 } \\
\text { 가해주어야 하는 정보를 찾기 }\end{array}$ & \multirow{2}{*}{$\begin{array}{l}\text { 중재자: 이건 뭐야? } \\
\text { (옳지 않은 반응) 아동: 막대기요. } \\
\text { 중재자: 막대기처럼 생겼네. 이건 낚시대야. 낚싯대는 물고 } \\
\text { 기를 잡는 거야. 그래서 낚싯대는 긴 줄과 바늘이 있어. } \\
\text { (옳은 반응) } \\
\text { 아동: 낚싯대. } \\
\text { 중재자: 그래, 이건 물고기를 잡는 낚싯대야. }\end{array}$} \\
\hline $\begin{array}{l}\text { 확장/확대(Expand/ } \\
\text { Extend) }\end{array}$ & & $\begin{array}{l}\text {-반응이 옳은 경우, 아동의 발화를 확장/ 확대 } \\
\text {-반응이 옳지 않은 경우, 아동이 맞는 답을 찾을 수 } \\
\text { 있도록 부족한 정보를 제공 }\end{array}$ & \\
\hline 반복(Repeat) & & 중재자가 확장/확대해 준 발화를 아동이 반복 & $\begin{array}{l}\text { 중재자: 선생님이 이게 뭐라고 했는지 다시 말해볼래? } \\
\text { 아동: 물고기를 잡는 낚싯대. }\end{array}$ \\
\hline
\end{tabular}

Appendix 2. 이야기 자료 분석 예시

\begin{tabular}{|c|c|c|c|c|}
\hline \multirow{2}{*}{ 내용 } & \multirow{2}{*}{ T-unit 수 } & \multirow{2}{*}{ 종속절 유형 } & \multicolumn{2}{|c|}{ 이야기 문법 } \\
\hline & & & 범주 & 점수 \\
\hline 조지가 집에서 퍼즐놀이를 했어요. & 1 & & 장소 $1 /$ 등장인물 & 시간장소(2) \\
\hline (퍼즐을) 사탕처럼 생긴 퍼즐을 먹어서 배가 아팠어요. & 1 & $\begin{array}{l}\text { 관형절 } \\
\text { 부사절 }\end{array}$ & 계기사건 & $\begin{array}{l}\text { 등장인물⑵ } \\
\text { 계기사건(2) }\end{array}$ \\
\hline (어떤 사람들이...) 병원에서 조지는 엑스레이를 찍었어요. & 1 & & 장소2/시도 & $\begin{array}{l}\text { 내적반응(0) } \\
\text { 계획(0) }\end{array}$ \\
\hline 조지가 수술실로 가서 수술을 했어요. & 1 & 부사절 & 결과 & 시도(2) \\
\hline 조지는 수술을 다 끝나서 밥을 다 먹었어요. & 1 & 부사절 & & 결과(2) \\
\hline
\end{tabular}

Appendix 3. 이야기 문법 분석 기준

\begin{tabular}{|c|c|c|c|c|}
\hline 유형 & 0점 & 1점 & 2점 & 3점 \\
\hline 시간/장소 & 특정 장소나 시간의 언급이 없음 & $\begin{array}{l}\text { 이야기와 관련이 없는 일반적인 시간 } \\
\text { 이나 장소언급 }\end{array}$ & $\begin{array}{l}\text { 이야기와 관련된 특정 장소나 시간 중 } \\
\text { 1가지를 언급 }\end{array}$ & $\begin{array}{l}\text { 이야기와 관련된 특정 장소와 시간 } \\
\text { 2가지 모두를 언급 }\end{array}$ \\
\hline 등장인물 & $\begin{array}{l}\text { 등장인물에 대한 언급이 없는 } \\
\text { 경우나 모호한 대명사 사용 }\end{array}$ & $\begin{array}{l}\text { 특정이름이나 설명 없이 적어도 하나 } \\
\text { 의 주인공이나 등장인물을 언급한 } \\
\text { 경우 }\end{array}$ & $\begin{array}{l}\text { 이름을 사용하여 적어도 } 1 \text { 명의 주인공 } \\
\text { 이 언급된 경우 }\end{array}$ & $\begin{array}{l}\text { 주인공의 이름과 특정 설명을 사용하 } \\
\text { 여 2명 이상의 등장인물을 언급한 } \\
\text { 경우 }\end{array}$ \\
\hline 계기사건 & $\begin{array}{l}\text { 이야기를 시작하게 되는 문제나 } \\
\text { 사건이 없는 경우 }\end{array}$ & $\begin{array}{l}\text { 적어도 하나의 사건이나 문제를 포함 } \\
\text { 하지만 등장인물의 행동이나 동기에 } \\
\text { 대한 언급이 없음 }\end{array}$ & $\begin{array}{l}\text { 적어도 하나의 사건이나 문제를 포함 } \\
\text { 하며 등장인물의 행동이나 동기를 } \\
\text { 언급 }\end{array}$ & $\begin{array}{l}\text { 하나의 이야기 안에서 } 2 \text { 가지 이상의 } \\
\text { 계기사건 포함 }\end{array}$ \\
\hline 내적반응 & 느낌, 바람에 대한 언급이 없음 & $\begin{array}{l}\text { 계기사건과 직접적인 관련 없이 일반 } \\
\text { 적으로 감정을 표현하는 단어 사용 }\end{array}$ & $\begin{array}{l}\text { 적어도 하나의 계기사건과 관련하여 } \\
\text { 감정, 바람, 생각을 표현 }\end{array}$ & $\begin{array}{l}\text { 계기사건과 관련된 2가지 이상의 감정 } \\
\text { 또는 생각을 표현 }\end{array}$ \\
\hline 계획 & $\begin{array}{l}\text { 문제해결을 위한 주인공의 } \\
\text { 계획이 제시되어 있지 않음 }\end{array}$ & $\begin{array}{l}\text { 미래지향적 상태동사나 인지, 정신적 } \\
\text { 표현을 사용했으나 계기사건과 직접 } \\
\text { 적인 관련이 없음 }\end{array}$ & $\begin{array}{l}\text { 계기사건에 관련하여 주인공의 계획에 } \\
\text { 대한 진술이 있음 }\end{array}$ & $\begin{array}{l}\text { 계기사건에 대한 주인공의 반응으로 } \\
\text { 2가지 이상의 계획에 대한 진술이 } \\
\text { 있음 }\end{array}$ \\
\hline 시도 & $\begin{array}{l}\text { 주요등장인물의 어떠한 행동이 } \\
\text { 없음 }\end{array}$ & $\begin{array}{l}\text { 직접적인 계기사건과 관련 없이 주인 } \\
\text { 공에 의해 수행되는 행동 언급 }\end{array}$ & $\begin{array}{l}\text { 하나 이상의 행동으로 직접적으로 } \\
\text { 계기사건과 관련되어 언급 }\end{array}$ & $\begin{array}{l}\text { 계기사건에 대한 반응으로 나타난 주 } \\
\text { 인공의 행동과 함께 시도의 유기적인 } \\
\text { 행동에 대한 언급 }\end{array}$ \\
\hline 결과 & 시도에 대한 결과가 없음 & $\begin{array}{l}\text { 계기사건 없이 등장인물이나 주인공의 } \\
\text { 행동에만 연결된 설명 }\end{array}$ & $\begin{array}{l}\text { 계기사건이나 시도와 연결된 하나의 } \\
\text { 결과 }\end{array}$ & $\begin{array}{l}\text { 계기사건이나 시도와 연결된 2가지 } \\
\text { 이상의 결과 }\end{array}$ \\
\hline
\end{tabular}

Petersen, Gillam, Spencer, \& Gillam (2010). 


\section{국문초록}

\section{6-7세 언어발달지체 아동의 이야기에 대한 ‘대화식 책 읽기’ 효과}

\section{강영희 ${ }^{1}$ 홍경훈 ${ }^{2}$}

1맘앤소리아동발달센터, ${ }^{2}$ 나사렛대학교 언어치료학과

배경 및 목적: 본 연구의 목적은 '대화식 책 읽기' 기법이 6-7세 언어발달지체 아동들의 이야기 회상 산출에 미치는 효과를 검증하는 데 있었다. 방법: 연구대상은 유치원생 1 명, 초등 1 학년 2 명의 언어발달지체 아동 3 명이었다. 자료는 기초선 3 회, 중재 16 회, 유지 3 회 동안 수집하였다. 중재 방법은 아동과 함께 책을 보면서 대화식 책 읽기의 PEER (자극, 평가, 확장, 반복) 전략을 사용하여 아동의 이야기 산 출을 촉진하였다. 분석한 변인들은 대형구조 측면에서 이야기 문법, 이야기 문법 하위 유형, 소형구조 측면에서 T-unit, TNW, MLT-w, 절밀도, 종속절 유형이었다. 결과: 모든 대상 아동들이 이야기 산출의 대형구조 및 소형구조의 모든 변인들에서 중재에 따른 증가 및 유 지를 나타냈다. 대형구조인 이야기 문법 측면에서 대상자들은 공통적으로 '등장인물', '계기사건', '시도', '결과'의 산출에서 큰 증가를 보 였으며, 특히 중재 전에 거의 산출되지 않았던 '내적반응'과 '계획'이 중재 이후 지속적으로 산출되었다. 소형구조 변인들은 모두 중재기 잔 대비 상당한 양적 증가를 나타냈다. 논의 및 결론: 대화식 책 읽기의 전략들이 학령기 언어발달지체 아동들의 이야기 회상산출의 대 형구조 및 소형구조 능력 향상에 상당한 효과가 있는 것으로 보인다.

핵심어: 대화식 책 읽기, 학령기 언어발달지체 아동, 이야기문법, T-unit, 종속절

본 연구는 제1저자의 석사학위논문을 수정·보완하여 재기술하였음.

\section{참고문헌}

곽금주, 오상우, 김청택(2011). 웩슬러 아동용 지능검사(K-WISC-IV). 서울: 학지사.

김유정, 배소영(2004). 학령전 단순언어장애 아동과 정상언어발달 아동의 이야기능력. 한국심리학회지발달, 17,41-58

김자성, 김정미(2011). 설명과 경험이야기에 나타난 학령기 아동 및 청소년의 구문발달 특성. 언어청각장애연구, 16, 540-558.

박찬화, 김명순(2010). 그림책읽기 언어중재프로그램이 저소득 가정 아동의 언어능력에 미치는 종단적 영향. 아동학회지, 31, 117-138.

배소영, 권유진(2006). 이야기 다시 말하기 과제를 통한 초등 저학년 아동의 이야기 능력. 언어청각장애연구, 11, 72-89.

배소영, 임선숙, 이지희(2000). 언어문제해결력검사. 서울: 서울장애인종합복지관.

배소영, 임선숙, 이지희, 장혜성(2004). 구문의미이해력검사. 서울: 서울장애인종합복지관.

오영신, 김정미, 이수향(2008). 대화식 책읽기 부모교육 프로그램이 언어발달지체아동의 발화와 부모의 행동에 미치는 효과. 유아특수교육 연구, 8,

139-154.

이미화, 김명순(2004). 영아를 위한 대화식 그림책읽기 교사교육 프로그램의 효과. 아동학회지, 25, 41-57.

채종옥(1995). 동화책 읽어주기 접근법에 따른 유아의 반응에 관한 연구. 이화여자대학교대학원 박사학위논문.

천선희, 김정미(2007). 스토리맵 중심 언어중재가 정신지체 아동의 이야기 이해와 산출에 미치는 효과. 언어청각장애연구, 12, 429-446. 